\title{
MODEL PENGELOLAAN SAMPAH BERBASIS MASYARAKAT DI KOTA DENPASAR
}

\author{
Made Armadi $^{*}$, , Wayan Suarna ${ }^{3)}$, Made Sudarma ${ }^{2)}$, Made Sudiana Mahendra ${ }^{2)}$, \\ Nyoman Sudipa ${ }^{4)}$ \\ ${ }^{1)}$ Dinas Kehutanan dan Lingkungan Hidup, Provinsi Bali. \\ ${ }^{2)}$ Program Doktor Ilmu Lingkungan, Universitas Udayana \\ ${ }^{3)}$ Fakultas Peternakan, Universitas Udayana \\ ${ }^{4)}$ Fakultas Teknik, Universitas Mahendradatta \\ *Email: adearmadi@ rocketmail.com
}

\section{ABSTRACT \\ COMMUNITY-BASED WASTE MANAGEMENT MODEL IN DENPASAR CITY}

Garbage is a problem that must be faced by the community, because garbage is a form of environmental pollution, where garbage can have an impact on public health, such as; odors, floods, destroy aesthetics, fire, greenhouse effect and so on. Household waste management requires active community participation so that the role of the government does not get heavier. Increase community participation in waste management in Denpasar City. In an effort to build the effectiveness of waste management in Denpasar City, it is necessary to develop a community-based waste management model in Denpasar City. The purpose of developing a waste management model is to actively involve the community in managing waste in Denpasar City. This study uses the Interpretative Structural Modeling (ISM) method approach by using elements of the affected community, elements of program objectives, elements of indicators to achieve goals, elements of the main constraints and elements of the institutions involved. In compiling the sub-elements from each element, it involves figures, experts, actors and activists in Denpasar City on community-based waste management. The results of the modeling show that the participatory role of the community is very important in reducing waste through reuse, increasing community involvement and implementing $3 \mathrm{R}$ activities. The main obstacle in waste management is the limited facilities and infrastructure for waste management and the unclear waste management organization. Possible changes are that law enforcement and waste regulations must be clear and the involvement of all stakeholders in community-based waste management in Denpasar City.

Keywords: model; management; waste; society.

\section{PENDAHULUAN}

Pertumbuhan penduduk memacu produksi sampah seiring dengan laju konsumsi dan meningkatnya pendapatan masyarakat (masyarakat berpendapatan tinggi, sedang dan rendah) pada umumnya (Riswan et al, 2011). Tujuan dari pengelolaan persampahan adalah untuk meningkatkan derajat kesehatan masyarakat dan meningkatnya kesehatan lingkungan, melindungi sumber air bersih yang berasal dari alam, meningkatnya kualitas sosial ekonomi dan sektor strategis (Rahardyan dan Widagdo, 2015). Sampah bisa menimbulkan dampak terhadap lingkungan terutama dampak terhadap air lingkungan dan meimbulkan berbagai penyakit (Sudipa, 2020). Pengelolaan sampah rumah tangga memerlukan partisipasi aktif dari berbagai komponen dan pemangku kepentingan untuk 
meringankan beban lingkungan hidup. Pengelolaan sampah sebaiknya diajarkan sejak dini untuk mendorong partisipasi dimasa mendatang dengan membudayakan perilaku pengelolaan sampah dari rumah tangga sebagai struktur terendah produsen sampah dan pengelola sampah perkotaan (Nurdin, 2014). Sistem pengelolaan sampah dengan partisipasi masyarakat sangat diharapkan di Kota Denpasar. Pelibatan masyarakat menjadi penting untuk dibuatkan model pengelolaan sampah yang cocok dan adaptif dengan kondisi Kota Denpasar untuk menyelesaikan permasalahan pengelolaan sampah (Mitchell, 2015). Pengembangan model tersebut nantinya dikembangkan di masyarakat untuk pengelolaan sampah berkelanjutan (Kholil et al., 2004). Model pengelolaan sampah sebaiknya melibatkan peran seluruh pemangku kepentingan secara patisipatif sebagai representasi masyarakat (Sudipa et al, 2020).

Salah satu model yang banyak diterapkan dalam pengelolaan sampah berbasis masyarakat adalah dengan ISM (Interpretative Struktural Modeling) yaitu sebuah teknik pemodelan yang dikembangkan untuk membuat strategi dari perencanaan (Marimin: 2004). Menurut Attri et al. (2013) dalam pelaksanaan model ISM, untuk menganalisis elemen-elemen komplek dan menyederhanakan menjadi hubungan grafis dari antar elemen dan tingkat hirarki.

\section{METODOLOGI}

Pengelolaan sampah dengan melibatkan peran aktif masyarakat sangat penting untuk mewujudkan Kota Denpasar yang bersih. Dalam upaya mengelola dari tingkat terkecil yaitu rumah tangga dan merumuskan model pengelolaan sampah rumah tangga di Kota Denpasar. Elemenelemen yang dipilih menyusun model pengelolaan sampah berbasis masyarakat di Kota Denpasar adalah elemen-elemen yang dominan memiliki peran dalam mendukung keberhasilan dalam pengelolaan sampah di Kota Denpasar.
Analisis ini dilakukan secara bertahap dan sistematis dengan memilih elemen yang memiliki pengaruh dominan dalam pengelolaan sampah yang didapatkan dari wawancara dengan pakar, tokoh dan penggiat pengelolaan sampah di Kota Denpasar. Strategi implementasi dirumuskan dengan menggunakan pendekatan Interpretative Struktural Modeling (ISM). Menurut Attri et al. (2013) tahapan-tahapan penerapan ISM sebagai berikut :

1. Identifikasi elemen- elemen sistem pengelolaan sampah rumah tangga di Kota Denpasar. Data ini dapat diperoleh melalui pendalaman dan wawancara, dan lain-lain.

2. Hubungan kontekstual antar elemen yang disusun berdasarkan tujuan pemodelan yang akan dibangun.

3. (Struktural Self Interaction Matrix (SSIM). Matriks ini mewakili elemen persepsi responden terhadap elemen tujuan yang dituju. Pembuatan matriks ini berdasarkan persepsi responden yang dimintakan melalui wawancara terfokus.

4. Penyusunan Matriks Reachibility Matriks (RM) bertujuan untuk mengubah simbolsimbol SSIM (Struktural Self Interaction Matrix.

5. Mengukur partisipasi masyarakat dilakukan untuk mengklasifikasikan elemen-elemen dari struktur ISM.

6. Pengelompokan elemen-elemen dalam level yang sama.

7. Menyusun diagrap.

\section{HASIL DAN PEMBAHASAN}

Berdasarkan hasil diskusi dan wawancara dengan para tokoh, pakar, pelaku dan aktivis Kota Denpasar. Adapun elemen yang dipilih yaitu (1) elemen masyarakat yang terpengaruh, (2) elemen tujuan program, (3) elemen untuk indikator mencapai tujuan, (4) elemen kendala utama dan (5) elemen perubahan yang dimungkinkan, dan (6) elemen lembaga yang terlibat. 


\section{Elemen Masyarakat yang terpengaruh}

Dari hasil diskusi dan wawancara dengan para tokoh, pakar, pelaku dan aktivis di Kota Denpasar terhadap pengelolaan sampah berbasis masyarakat di Kota Denpasar diperoleh 7 sub elemen yaitu:

A1. Ibu Rumah Tangga.

A2. Pemulung.

A3. Tokoh Masyarakat.

A4. Tokoh Agama.

A5. Pelajar dan Pemuda.

A6. penghasil kompos.

A7. pengguna kompos.

Penilaian hubungan konstektual antar sub elemen masyarakat yang terpengaruh dengan pendekatan $\mathrm{V}, \mathrm{A}, \mathrm{X}$ dan $\mathrm{O}$ dalam Gambar 1. Hasil analisis terhadap 7 sub elemen masyarakat yang terpengaruh menunjukkan bahwa sub elemen kunci adalah Ibu Rumah Tangga (1), Tokoh Masyarakat (3), Tokoh Agama dan Pelajar dan Pemuda (5). Hal ini menunjukkan bahwa elemen masyarakat yang berpengaruh dalam pengelolaan sampah berbasis rumah tangga adalah Ibu Rumah Tangga, Tokoh Masyarakat, Tokoh Agama dan Pelajar dan Pemuda, serta mempunyai daya dorong yang kuat untuk mewujudkan pengelolaan sampah berbasis rumah tangga. Sub elemen ini harus menjadi pusat kekuatan untuk mengungkit keberhasilan pelaksanaan pengelolaan sampah berbasis masyarakat.

\begin{tabular}{|c|c|c|c|c|c|c|c|}
\hline No. & A1 & $\mathrm{A} 2$ & A3 & A4 & A5 & A6 & A7 \\
\hline A1 & & V & 0 & 0 & 0 & V & V \\
\hline $\mathrm{A} 2$ & & & 0 & 0 & 0 & 0 & 0 \\
\hline A3 & & & & $X$ & V & V & V \\
\hline A4 & & & & & V & $\mathrm{V}$ & V \\
\hline A5 & & & & & & $\mathrm{V}$ & $\mathrm{V}$ \\
\hline A6 & & & & & & & $\mathrm{V}$ \\
\hline A7 & & & & & & & \\
\hline
\end{tabular}

Gambar 1.

Hubungan konstektual antar sub elemen masyarakat yang terpengaruh

Disamping itu sub elemen Ibu Rumah Tangga (1), Tokoh Masyarakat (3), Tokoh
Agama dan Pelajar dan Pemuda (5) berdasarkan Driver Power dan Dependence berada di sektor IV (Independent), yang berarti sub elemen tersebut juga mempunyai daya ungkit dan daya penggerak yang kuat terhadap elemen masyarakat terpengaruh. Sub elemen Penghasil Kompos (6) dan sub elemen Pengguna Kompos berdasarkan Driver Power dan Dependence berada di sektor II (Dependence) yang berarti sub elemen tersebut adalah sub elemen yang mempunyai pengaruh yang kecil dan memiliki ketergantungan dengan sub elemen Ibu Rumah Tangga (1), Tokoh Masyarakat (3), Tokoh Agama dan Pelajar dan Pemuda (5) dalam mendukung elemen masyarakat terpengaruh dalam menyusun model pengelolaan sampah berbasis masyarakat di Kota Denpasar. Komitmen pemerintah dan perangkat pendukungnya dibutuhkan untuk mengerakkan berbagai komponen, penguatan sumber daya manusia dan memberikan dukungan pendanaan dalam pengelolaan sampah berbasis masyarakat dengan memaksimalkan peranan sub elemen Ibu Rumah Tangga (1), Tokoh Masyarakat (3), Tokoh Agama dan Pelajar dan Pemuda (5) sebagai penggerak utama sektor masyarakat yang terpengaruh (Gambar 2).

Struktur model hirarki kendala utama model pengelolaan sampah berbasis masyarakat di Kota Denpasar yang berdasarkan pengelompokan tertera pada Gambar 3. Sub elemen yang lebih tinggi mempunyai pengaruh kepada level yang lebih rendah.

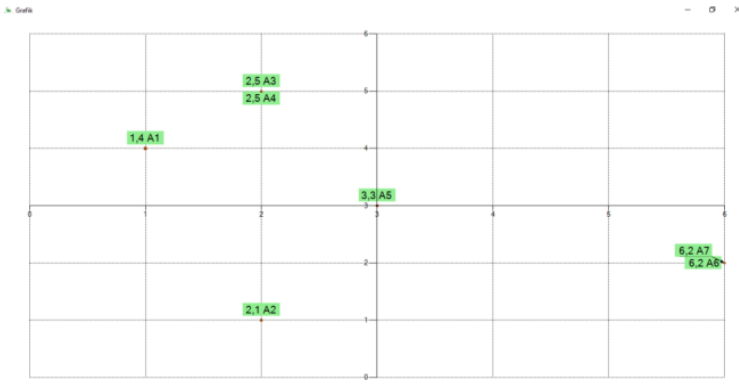

Gambar 2.

Kuadran hubungan konstektual antar sub elemen masyarakat yang terpengaruh 


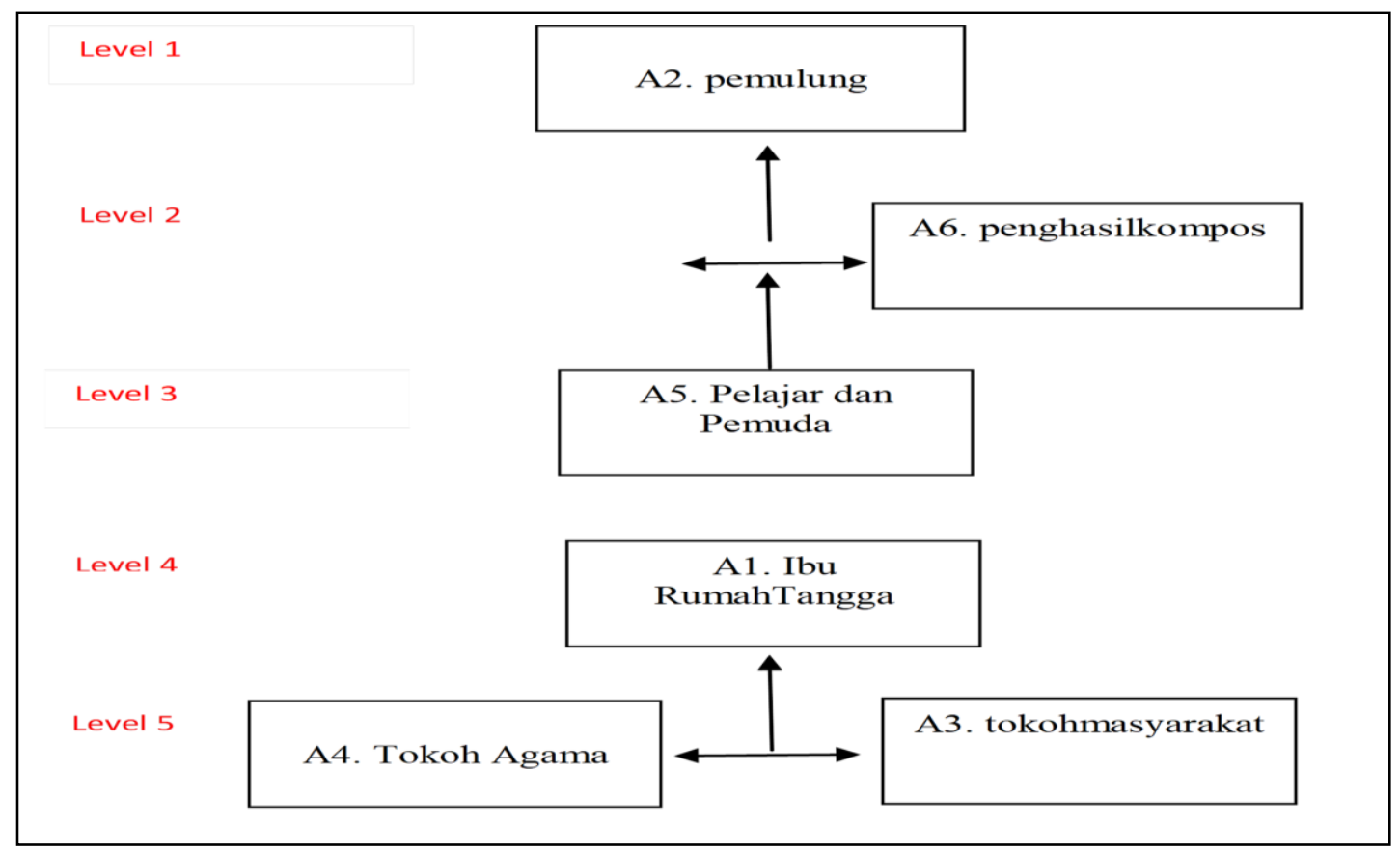

Gambar 3.

Struktur model hirarki sub elemen masyarakat yang terpengaruh

Peningkatan kualitas sumber daya manusia dan memberikan dukungan pendanaan harus ditempatkan sebagai kunci utama untuk mendukung keberhasilan pelaksanaan dalam pengelolaan sampah. Sumber daya manusia yang dimaksudkan adalah sumber daya yang berasal dari masyarakat lokal dan para tokoh formal sebagai motor penggerak utama secara partisipatif dengan melibatkan multi sektor mulai dari pemerintah, masyarakat lokal, lembaga swadaya masyarakat, pengusuha dan dunia pendidikan dengan didukung sumber pendanaan yang jelas.

\section{Elemen Tujuan Program}

Dari hasil diskusi dan wawancara dengan para tokoh, pakar, pelaku dan aktivis di Kota Denpasar terhadap model pengelolaan sampah berbasis masyarakat di Kota Denpasar diperoleh 6 sub elemen yaitu: G1. mengurangi sampah di sumber.

G2. memanfaatkan sampah kembali.

G3. melakukan daur ulang sampah.

G4. meningkatkan keterlibatan.

G5. meningkatkan pendapatan masyarakat.

G6. mengurangi biaya operasional.

Penilaian pakar terhadap hubungan konstektual antar sub elemen tujuan program dengan pendekatan $\mathrm{V}, \mathrm{A}, \mathrm{X}$ dan $\mathrm{O}$ dalam Gambar 4.

Dari 6 sub elemen tujuan program yang menjadi sub elemen kunci adalah mengurangi sampah di sumber (1), memanfaatkan sampah kembali (2), melakukan daur ulang sampah (3), meningkatkan keterlibatan masyarakat (4), meningkatkan pendapatan masyarakat (5), dan mengurangi biaya operasional (6). Walapun sebagai sub elemen kunci tetapi sub elemen ini berdasarkan Driver Power dan Dependence berada di sektor III (Linkage), yang berarti sub elemen tersebut sentitif dan tidak stabil sehingga perlu kehati-hatian dalam aplikasi menyusun model pengelolaan sampah berbasis masyarakat di Kota Denpasar. Sub elemen meningkatkan memanfaatkan sampah kembali (2) dan sub elemen meningkatkan keterlibatan masyarakat (4) merupakan sub elemen yang paling kuat diantara keenam sub elemen lainnya, tetapi diperlukan kehati-hatian dalam penerapannya karena elemen ini tidak stabil dan sensitif. Sub elemen mengurangi sampah di sumber (1), melakukan daur ulang sampah (3), dan sub elemen meningkatkan pendapatan masyarakat (5) merupakan sub elemen yang berada hirarki berikutnya tetapi 
lebih lemah dibandingkan dengan sub elemen meningkatkan memanfaatkan sampah kembali (2) dan sub elemen meningkatkan keterlibatan masyarakat (4). Sedangkan sub elemen mengurangi biaya operasional (6) merupakan elemen terlemah yang perlu kehati-hatian dalam penggunaannya. Sub elemen ini berfungsi sebagai elemen pendukung tujuan program pengelolaan sampah di Kota Denpasar berbasis masyarakat (Gambar 5.).

\begin{tabular}{|c|c|c|c|c|c|c|}
\hline No. & G1 & $\mathrm{G} 2$ & G3 & G4 & G5 & G6 \\
\hline G1 & & \multirow[t]{6}{*}{$X$} & $X$ & $x$ & 0 & $X$ \\
\hline $\mathrm{G} 2$ & & & $x$ & $x$ & $x$ & $X$ \\
\hline G3 & & & & $A$ & $x$ & $\mathrm{~V}$ \\
\hline G4 & & & & & $x$ & V \\
\hline G5 & & & & & & V \\
\hline G6 & & & & & & \\
\hline
\end{tabular}

Gambar 4

Hubungan konstektual antar sub elemen tujuan program
Struktur model hirarki tujuan program dalam menyusun model pengelolaan sampah di Kota Denpasar yang berdasarkan pengelompokan tertera pada Gambar 6. Sub elemen yang lebih tinggi mempunyai pengaruh kepada level yang lebih rendah.



Gambar 5.

Kuadran hubungan konstektual antar sub elemen tujuan program

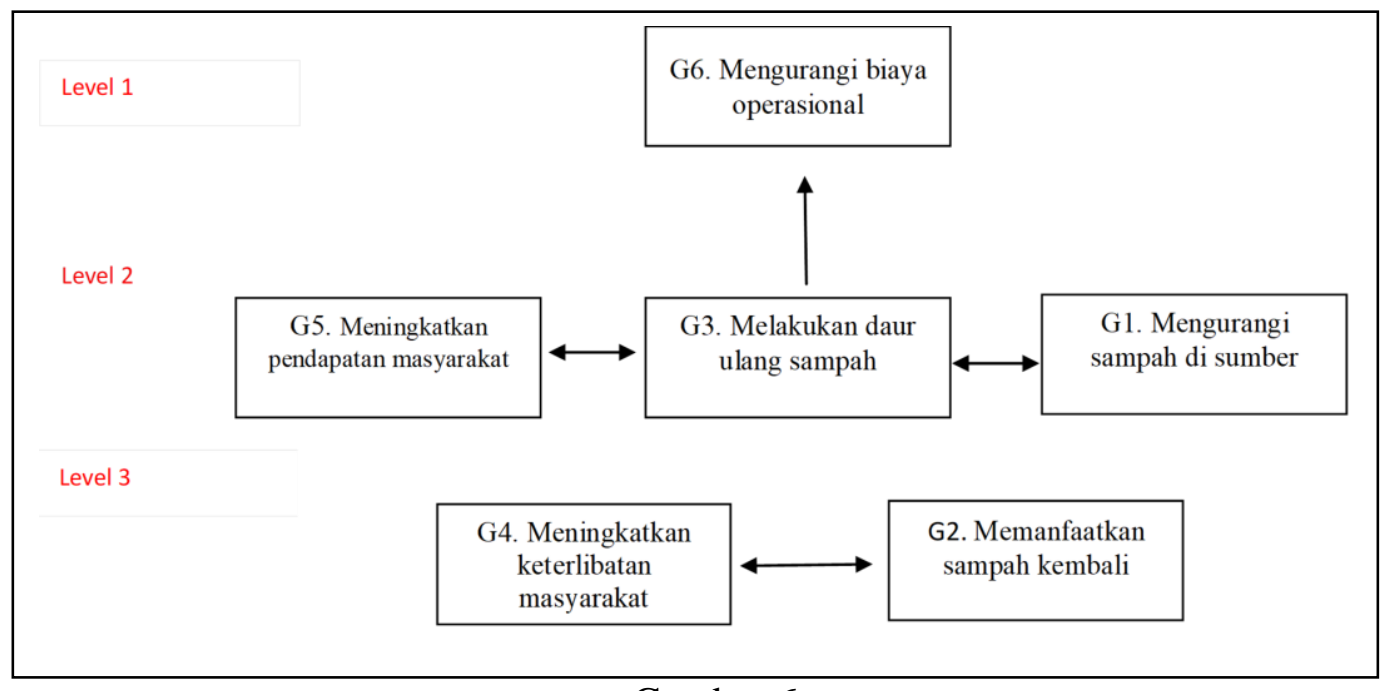

Gambar 6.

Struktur model hirarki tujuan program

Dalam menerapkan tujuan program sebaiknya dilakukan dengan hati-hati, karena hal ini berhubungan dengan regulasi pemerintah dan berhubungan dengan keterlibatan masyarakat dalam pengelolaan sampah dalam upaya pemanfaatan sampah kembali yang dilakukan melalui daur ulang sampah dan mengurangi sampah pada sumber sampah yang pada akhirnya untuk meningkatkan pendapatan masyarakat.
Tujuan berikutnya adalah mengurangi biaya operasional pengelolaan sampah apabila sampah rumah tangga telah selesai pada tingkat masyarakat sehingga residu yang dihasilkan mampu ditekan dan sampah sedikit mungkin di buang ke TPA.

Menerapkan kebijakan yang berhubungan dengan tujuan program pengelolaan sampah rumah tangga sebaiknya dilakukan dengan melibatkan lintas sektor 
seperti pemerintah, masyarakat lokal, pengusaha, lembaga adat, lembaga swadaya masyarakat dan para pemerhati lingkungan. Muara dari tujuan program pengelolaan sampah berbasis masyarakat adalah memperkuat system pengelolaan sapah di tingkat masyarakat dengan peran pemerintah memberikan support kabijakan atau regulasi, pembinaan, pengawasan dan pendanaan.

3. Elemen Indikator untuk Mencapai Tujuan

Dari hasil diskusi dan wawancara dengan para tokoh, pakar, pelaku dan aktivis di Kota Denpasar terhadap pengelolaan sampah berbasis masyarakat di Kota Denpasar diperoleh 4 sub elemen yaitu:

N1 Berkurangnya sampah.

N2 terlaksanananya kegiatan 3R.

N3 meningkatnya jumlah masyarakat yang mengelola sampah.

N4 meningkatnya pendapatan masyarakat.

Penilaian pakar terhadap hubungan konstektual antar sub elemen sektor masyarakat yang terpengaruhi dengan pendekatan V, A, X dan O dalam Gambar 7.

\begin{tabular}{|c|c|c|c|c|}
\hline No. & N1 & $\mathrm{N} 2$ & N3 & N4 \\
\hline N1 & & $X$ & A & $x$ \\
\hline N2 & & & $X$ & $\mathrm{~V}$ \\
\hline N3 & & & & V \\
\hline N4 & & & & \\
\hline
\end{tabular}

Gambar 7.

Hubungan konstektual antar sub elemen indikator untuk mencapai tujuan

Hasil analisis terhadap 4 sub elemen sektor masyarakat yang terpengaruhi menunjukkan bahwa yang menjadi sub elemen kunci adalah berkurangnya sampah (1), terlaksanananya kegiatan 3R (2), meningkatnya jumlah masyarakat yang mengelola sampah (3), dan meningkatnya pendapatan masyarakat (4) karena berdasarkan Driver Power dan Dependence berada di sektor III (Lingkages, dimana sub elemen tersebut juga memiliki daya dorong yang cukup kuat terhadap elemen indikator untuk mencapai tujuan, tetapi dalam penerapannya harus hati-hati karena sub elemen ini bersifat labil dan sensitif dalam menyusun elemen indikator untuk mencapai tujuan dalam model pengelolaan sampah berbasis masyarakat (Gambar 8).



Gambar 8.

Kuadran hub. konstektual antar sub elemen indikator untuk mencapai tujuan

Dari keempat sub elemen indikator untuk mencapai tujuan pengelolaan sampah berbasis masyarakat, sub elemen yang paling kuat adalah sub elemen terlaksanananya kegiatan 3R (2) dan sub elemen meningkatnya jumlah masyarakat yang mengelola sampah (3), yang artinya sub elelem ini paling berpengaruh dan mempengaruhi elelem lainnya. Kemudian disusul oleh sub elemen berkurannya samapah (1) dan sub elemen yang paling lemah adalah sub elemen meningkatnya pendapatan masyarakat (4), akan tetapi sub elemen tersebut sentitif dan tidak stabil sehingga perlu kehati-hatian dalam aplikasi menyusun model pengelolaan sampah berbasis masyarakat di Kota Denpasar.

Struktur model hirarki elemen indikator untuk mencapai tujuan dalam menyusun model pengelolaan sampah berbasis masyarakat di Kota Denpasar yang berdasarkan pengelompokan tertera pada Gambar 9. Sub elemen yang lebih tinggi mempunyai pengaruh kepada level yang lebih rendah. 


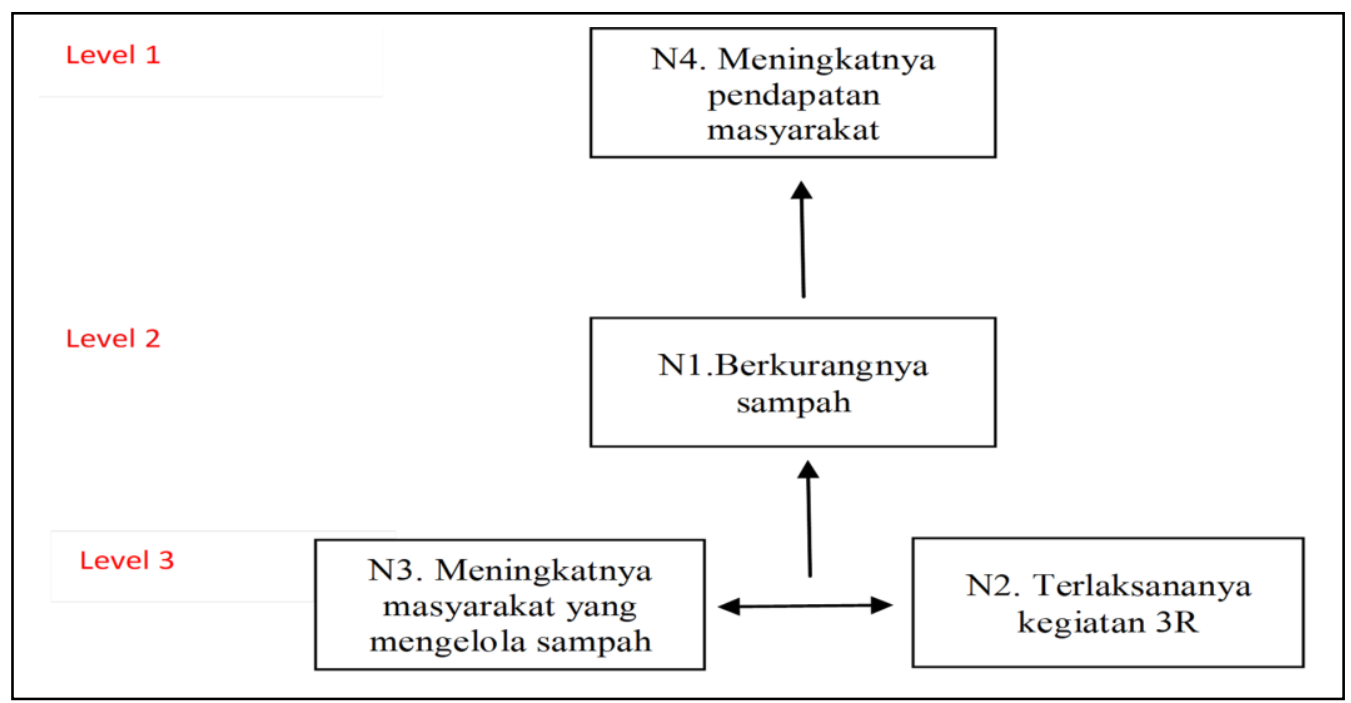

Gambar 9.

Struktur model hirarki indikator untuk mencapai tujuan

Dalam menyusun model pengelolaan sampah berbasis masyarakat di Kota Denpasar khususnya dalam menganalisis indikator untuk mencapai tujuan dalam pengelolaan sampah adalah terlaksananya kegiatan 3R dan meningkatnya masyarakat dalam mengelola sampah. Tetapi posisi meningkatnya masyarakat dalam mengelola sampah dan merupakan kunci penggerakan utama dalam menyusun model.

Inisiatif model pengelolaan sampah berbasis masyarakat di Kota Denpasar dimulai dengan melakukan pendekatanpendekatan formal dan informal dengan sektor masyarakat yang berpengaruh dan dilanjutkan dengan komitmen dalam mengelola lingkungan. Komitmen yang akan dibangun merujuk kepada tata aturan pemerintah yang mengakomodir peran serta pemerintah, masyarakat, lembaga swadaya masyarakat, pengusaha, lembaga adat, dll.

\section{Elemen Kendala Utama}

Dari hasil diskusi dan wawancara dengan para tokoh, pakar, pelaku dan aktivis di Kota Denpasar terhadap pengelolaan sampah berbasis masyarakat di Kota Denpasar diperoleh 10 sub elemen yaitu:

C1. terbatasnya sarana dan prasarana.

C2. terbatasnya anggaran.

C3. kurangnya pengetahuan masyarakat.

C4. kurangnya kesadaran masyarakat.
C5. terbatasnya sdm dibidang persampahan.

C6. regulasi yang kurang tegas.

C7. lemahnya penegakan hukum.

C8. sistem pelayanan yang masih rendah.

C9. koordinasi antar instansi yang masih kurang.

C10. struktur pengelola organisasi belum jelas.

Penilaian pakar terhadap hubungan konstektual antar sub elemen kendala utama dengan pendekatan $\mathrm{V}, \mathrm{A}, \mathrm{X}$ dan $\mathrm{O}$ dalam Gambar 10. Dari 10 sub elemen kendala utama, yang menjadi sub elemen kunci adalah terbatasnya anggaran (2), terbatasnya sumber daya manusia dibidang persampahan (5), regulasi yang kurang tegas (6), lemahnya penegakan hukum (7), karena berdasarkan berdasarkan Driver Power dan Dependence berada di sektor IV (Independent) merupakan elemen bebas dan mempunyai daya dorong yang kuat yang mampu mempengaruhi elemen kendala utama dalam penyusunan model. Sosialisasi dan pembinaan harus terus dilakukan untuk meningkatkan pengetahuan masyarakat dalam pengelolaan sampah, kesadaran masyarakat harus terus dibangun dan menciptakan kesadaran dengan mendidik atau memberikan edukasi di bidang persampahan, misalnya dengan mengadakan 
pelatihan dan pendidikan yang dilengkapi dengan sarana dan prasarana pendukung termasuk anggaran dan insentif. Regulasi yang sudah ada perlu dipertegas dengan menerapkan aturan hukum dan sangsi yang jelas sehingga masyarakat mematuhi ketentuan dalam pengelolaan sampah.

Sub elemen terbatasnya sarana dan prasarana (1), sistem pelayanan yang masih rendah (8), koordinasi antar instansi yang masih kurang (9), struktur pengelola organisasi belum jelas (10), berdasarkan Driver Power dan Dependence berada di sektor III (Linkage), artinya sub elemen ini mempunyai daya dorong yang cukup kuat, tetapi sub elemen ini bersifat sentitif dan tidak stabil sehingga perlu kehati-hatian dalam aplikasi menyusun model pengelolaan sampah berbasis masyarakat. Sedangkan sub lemen kurangnya pengetahuan masyarakat (3) dan kurangnya kesadaran masyarakat (4), merupakan sub elemen tidak bebas yang berada di sektor II (Dependent), elemen ini mempunyai daya dorong yang lemah dan berfungsi sebagai sub elemen pendukung kendala utama pengelolaan sampah berbasis masyarakat di Kota Denpasar (Gambar 11).

\begin{tabular}{|c|c|c|c|c|c|c|c|c|c|c|}
\hline No. & $\mathrm{C} 1$ & $\mathrm{C} 2$ & C3 & C4 & C5 & C6 & C7 & $\mathrm{C} 8$ & C9 & $\mathrm{C} 10$ \\
\hline $\mathrm{C} 1$ & & A & V & 0 & $x$ & A & 0 & $x$ & 0 & A \\
\hline C2 & & & V & V & v & 0 & A & V & A & $\mathrm{v}$ \\
\hline C3 & & & & $x$ & A & A & A & V & A & $\mathrm{v}$ \\
\hline C4 & & & & & A & A & A & $x$ & $v$ & $\mathrm{v}$ \\
\hline C5 & & & & & & v & A & $x$ & $x$ & $x$ \\
\hline C6 & & & & & & & $\mathrm{v}$ & $x$ & $x$ & $x$ \\
\hline C7 & & & & & & & & v & $v$ & A \\
\hline C8 & & & & & & & & & $\mathrm{v}$ & $A$ \\
\hline C9 & & & & & & & & & & $\mathrm{v}$ \\
\hline C10 & & & & & & & & & & \\
\hline
\end{tabular}

Gambar 10.

Hubungan konstektual antar sub elemen kendala utama

Struktur model hirarki elemen kendala utama dalam menyusun model pengelolaan sampah berbasis masyarakat di Kota Denpasar yang berdasarkan pengelompokan pada Gambar 12. Sub elemen yang lebih tinggi mempunyai pengaruh kepada level yang lebih rendah.

Dalam menyusun model pengelolaan sampah berbasis masyarakat di Kota Denpasar khususnya dalam menganalisis elemen kendala utama dalam pengelolaan sampah, secara hirarki sub elemen koordinasi antar instansi masih kurang menjadi peranan utama sebagai kendala utama dalam pengelolaan sampah di Kota Denpasar. koordinasi antar instansi secara vertikal perlu terus dilakukan dengan melibatkan kewenangan yang lebih tinggi sehingga koordinasi bisa berjalan dengan baik.

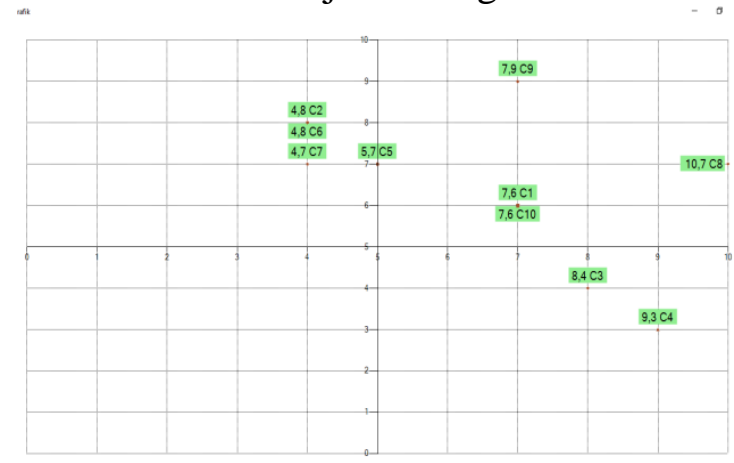

Gambar 11.

Kuadran hubungan konstektual antar sub elemen kendala utama

Langkah selanjutnya yang dilakukan untuk meminimalkan kendala utama adalah memperjelas regulasi dengan melakukan pengawasan dan sosialisasi dari regulasi yang telah disusun serta menegakkan regulasi di lapangan. Disamping itu dalam pengelolaan sampah perlu didukung oleh anggaran yang cukup memadai di setiap gugus tugas penanganan sampah. Langkah berikutnya adalah memperkuat sistem pelayanan, memperkuat penegakan hukum dan memperkuat sumber daya manusia di bidang persampahan untuk meminimalisir kendala utama pengelolaan sampah, diikuti dengan memperkuat sarana dan prasarana serta meningkatkan kesadaran masyarakat. 


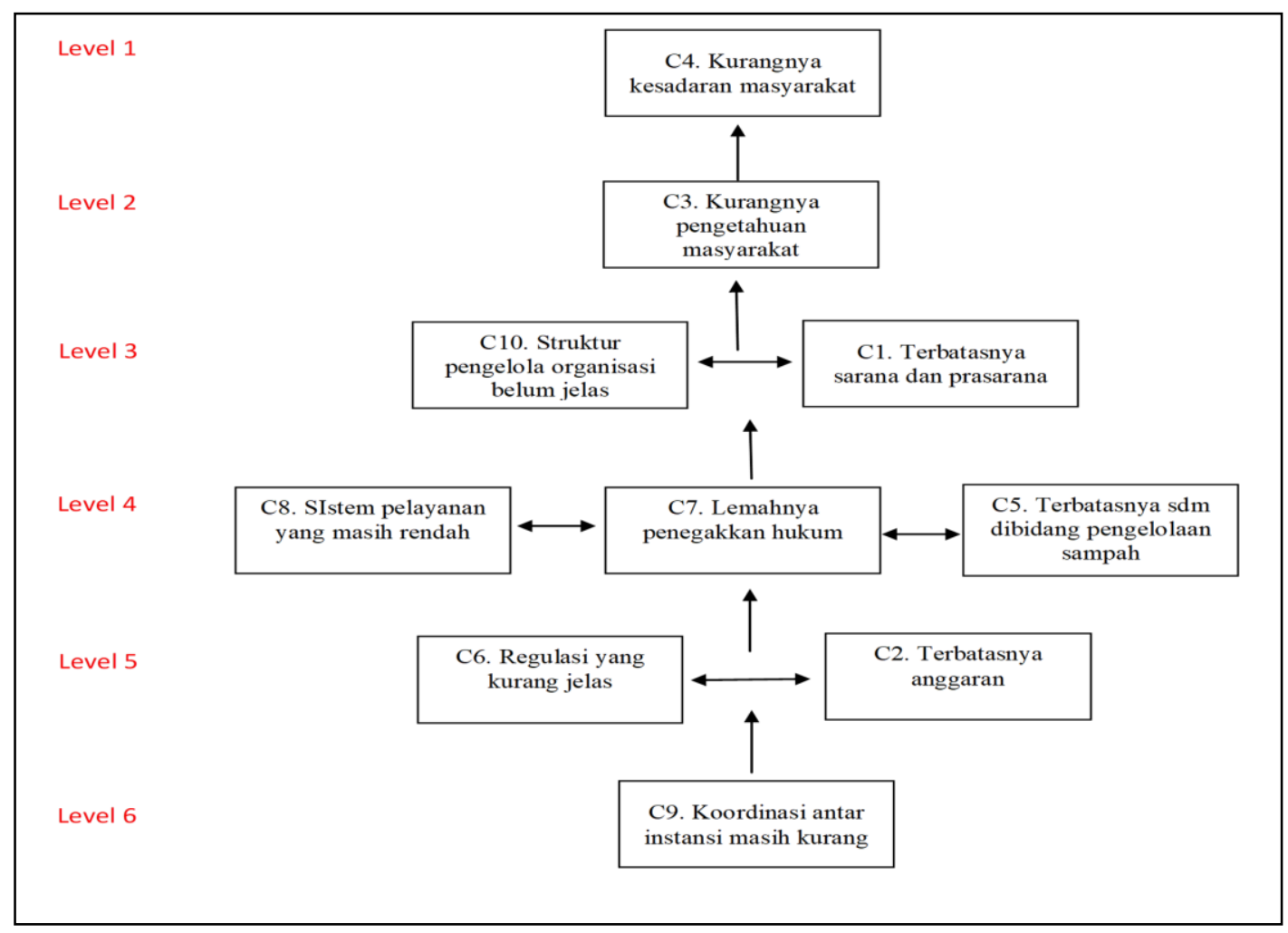

Gambar 12.

Struktur model hirarki kendala utama

\section{Elemen Perubahan yang Dimungkinkan}

Dari hasil diskusi dan wawancara dengan para tokoh, pakar, pelaku dan aktivis di Kota Denpasar terhadap pengelolaan sampah berbasis masyarakat di Kota Denpasar diperoleh 7 sub elemen yaitu:

P1. Volume sampah berkurang.

P2. kebersihan dan kesehatan lingkungan.

P3. kesadaran masyarakat meningkat.

P4. peraturan tentang sampah yang jelas.

P5. penegakan hukum harus jelas.

P6. biaya operasional menurun.

P7. pendapatan masyarakat meningkat.

Dari hubungan konstektual antar sub elemen perubahan yang dimungkinkan dengan pendekatan $\mathrm{V}, \mathrm{A}, \mathrm{X}$ dan $\mathrm{O}$ dalam Gambar 13. Dari 7 sub elemen perubahan yang dimungkinkan yang menjadi sub elemen kunci adalah peraturan tentang sampah yang jelas (4) dan penegakan hukum harus jelas (5), karena berdasarkan Driver Power dan Dependence berada di sektor IV (Independent) merupakan elemen bebas dan mempunyai daya dorong yang kuat yang mampu mempengaruhi elemen kendala utama dalam penyusunan model. Kunci dari elemen perubahan yang dimungkinkan dalam pengelolaan sampah adalah pada tataran regulasi dan penegakan hukum yang perlu dipertegas dan adanya reward serta punishment dalam memperkuat pengeloaan sampah.

Sub elemen terbatasnya sarana dan prasarana volume sampah berkurang (1), kebersihan dan kesehatan lingkungan (2), kesadaran masyarakat meningkat (3), pendapatan masyarakat meningkat (7), berdasarkan Driver Power dan Dependence berada di sektor III (Linkage), yang berarti sub elemen ini memiliki daya dorong tetapi sub elemen ini bersifat sentitif dan tidak stabil sehingga perlu kehati-hatian dalam aplikasi menyusun model pengelolaan sampah berbasis masyarakat. Sedangkan sub elemen biaya operasional menurun (6), adalah sub elemen tidak bebas dan berada di sektor II (Dependent), elemen ini berfungsi sebagai sub elemen pendukung perubahan 
yang dimungkinkan pengelolaan sampah berbasis masyarakat di Kota Denpasar (Gambar 14).

\begin{tabular}{|c|c|c|c|c|c|c|c|}
\hline No. & $\mathrm{P} 1$ & $\mathrm{P} 2$ & P3 & P4 & P5 & P6 & $\mathrm{P} 7$ \\
\hline P1 & & $X$ & $X$ & $A$ & $A$ & V & $X$ \\
\hline P2 & & & A & $A$ & $A$ & V & $x$ \\
\hline P3 & & & & A & A & $\mathrm{V}$ & A \\
\hline P4 & & & & & $X$ & V & V \\
\hline P5 & & & & & & V & $x$ \\
\hline P6 & & & & & & & A \\
\hline P7 & & & & & & & \\
\hline
\end{tabular}

Gambar 13.

Hubungan konstektual antar sub elemen perubahan yang dimungkinkan

Dalam menganalisis elemen perubahan yang dimungkinkan dalam pengelolaan sampah berbasis masyarakat, secara hirarkis penegakan hukum dan dan peraturan tentang sampah yang jelas menjadi hirarki tertinggi yang sebagai pendukung perubahan dalam pengelolaan sampah berbasis masyarakat dan berdampak kepada meningkatnya pendapatan masyarakat dan berkurangnya volume sampah pada hirarki berikutnya.

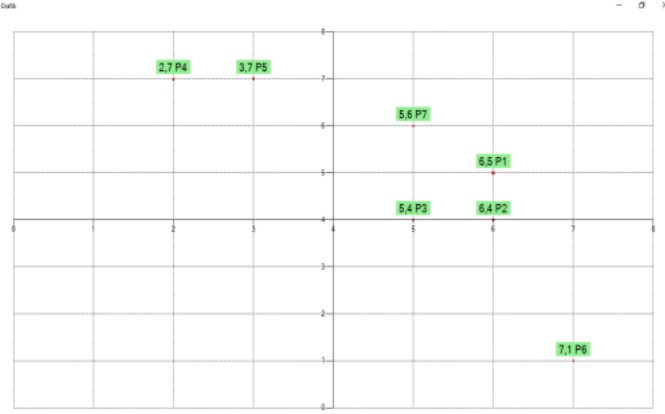

Gambar 14.

Kuadran hubungan konstektual antar sub elemen perubahan yang dimungkinkan

Kesadaran masyarakat, kebersihan dan kesehatan lingkungan menjadi hiraki berikutnya tetapi memiliki daya dorong yang lemah dalam memperkuat elemen perubahan yang dimungkinkan dalam pengelolaan sampah berbasis masyarakat di Kota Denpasar. Kesadaran masyarakat, kebersihan dan kesehatan lingkungan menjadi tujuan dalam pengelolaan sampah yang sangat ditentukan oleh penegakan hukum dan dan peraturan tentang sampah yang jelas. Sedangkan biaya operasional yang menurun merupakan dampak akhir dari serangkaian pelaksanaan hirarki dari sub elemen perubahan yang dimungkinkan dalam pengelolaan sampah berbasis masyarakat.

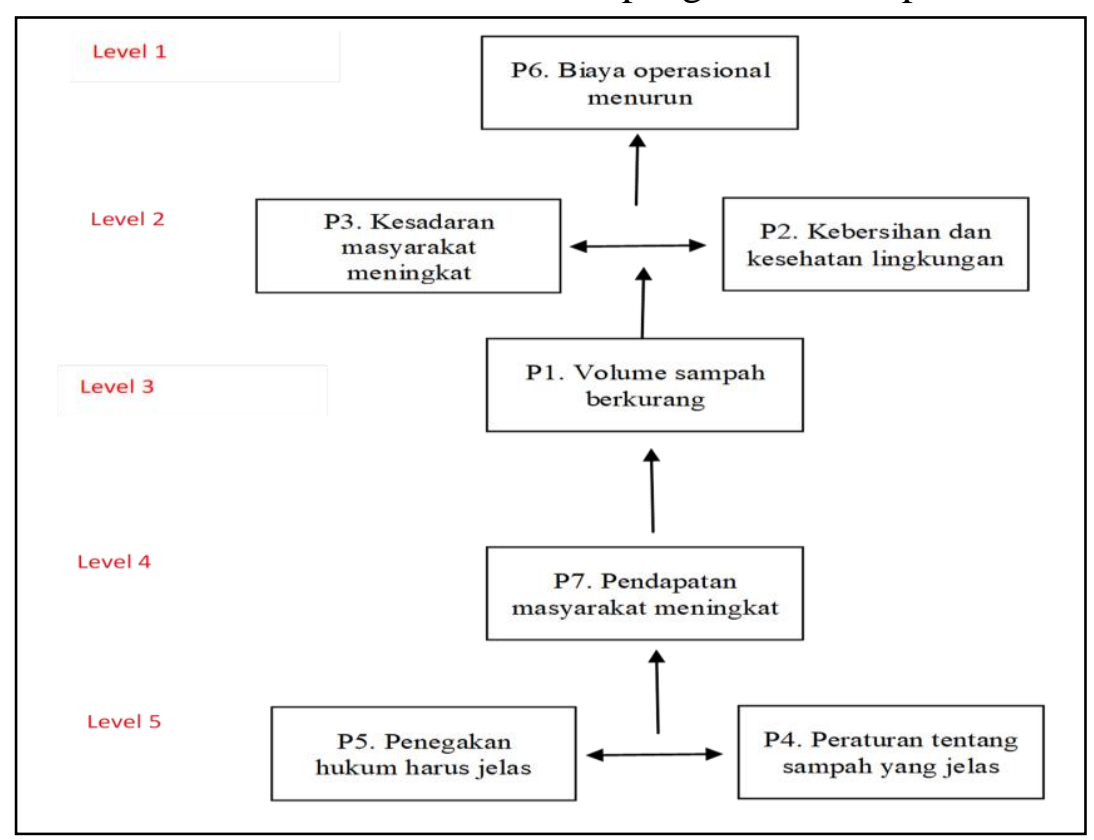

Gambar 15.

Struktur model hirarki perubahan yang dimungkinkan 


\section{Elemen Lembaga yang Terlibat}

Dari hasil diskusi dan wawancara dengan para tokoh, pakar, pelaku dan aktivis di Kota Denpasar terhadap pengelolaan sampah berbasis masyarakat di Kota Denpasar diperoleh 9 sub elemen yaitu:

C1. Walikota.

C2. Dinas Lingkungan Hidup Kota Denpasar.

C3. Camat.

C4. Desa Dinas.

C5. Desa Adat.

C6. Kelompok Swadaya Masyarakat.

C7. Media massa.

C8. LSM.

C9. Pengelola Bank Sampah.

Dari hubungan konstektual antar sub elemen lembaga yang terlibat dengan pendekatan V, A, X dan $\mathrm{O}$ dalam Gambar 16. Dari 9 sub elemen lembaga yang terlibat, sub elemen kunci adalah Walikota (1), Dinas Lingkungan Hidup Kota Denpasar (3), Camat (3), Desa Dinas (4), Desa Adat (5), Kelompok Swadaya Masyarakat (6), Media Massa (7), Lembaga Swadaya Masyarakat (8) dan Pengelola Bank Sampah (9), karena berdasarkan berdasarkan Driver Power dan Dependence berada di sektor III (Linkage), artinya sub elemen ini bersifat sentitif dan tidak stabil sehingga perlu kehati-hatian dalam aplikasi menyusun model pengelolaan sampah berbasis masyarakat (Gambar 17).

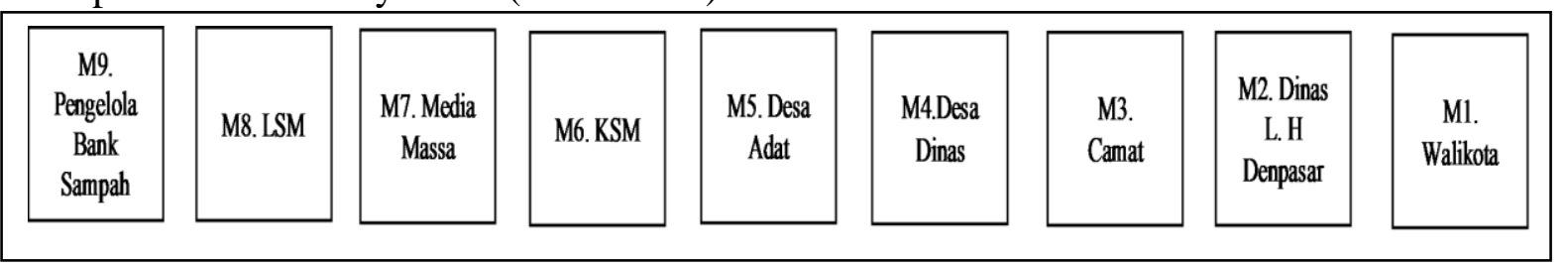

Gambar 18.

Struktur model hirarki lembaga yang terlibat
Gambar 16.

Hubungan konstektual antar sub elemen lembaga yang terlibat

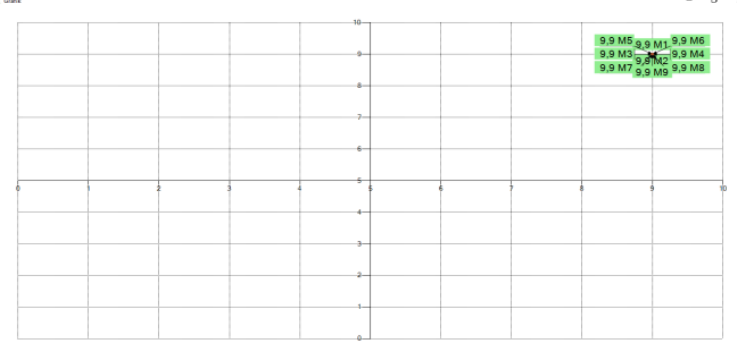

Gambar 17.

Kuadran hubungan konstektual antar sub elemen lembaga yang terlibat

Semua elemen yang terlibat dalam pengelolaan sampah di Kota Denpasar mempunyai peranan yang sama kuat untuk mendorong percepatan pengelolaan sampah berbasis masyarakat.

\section{SIMPULAN DAN SARAN}

\subsection{Simpulan}

Peranan masyarakat secara partisipatif sangat penting untuk mengurangi sampah melalui pemanfaatan kembali, meningkatkan keterlibatan masyarakat dan terlaksananya kegiatan 3R. Kendala utama dalam pengelolaan sampah adalah terbatasnya sarana dan prasarana pengelolaan sampah dan organisasi pengelola sampah belum jelas. Perubahan yang dimungkinkan 
adalah penegakan hukum dan peraturan sampah harus jelas dan pelibatan seluruh pemangku kepentingan dalam pengelolaan sampah berbasis masyarakat di Kota Denpasar.

\subsection{Saran}

Dalam praktek penyusunan model pengelolaan sampah berbasis masyarakat perlu melibatkan semua unsur pemangku kepentingan dalam pengambilan keputusan dan pelaksanaannya dilakukan dengan memperkuat sistem pelayanan dan penegakan hukum yang jelas.

\section{DAFTAR PUSTAKA}

Attri, R., Dev, N., dan Sharma, V. (2013). Interpretive Structural Modelling (ISM) Approach: An Overview. Research Journal of Management Sciences. 2(2), 3-8.

Kholil, Eriyatno, Sutjahyo, S., H, Soekarto, S., H. 2008. Pengembangan Model Kelembagaan Pengelola Sampah Kota dengan Metode ISM (Interpretative Structural Modelling) Studi Kasus di Jakarta Selatan; Jurnal Trandisiplin Sosiologi dan Ekologi Manusia: (2) 1:31-48

Marimin. 2004. Teknik dan Aplikasi Pengambil Keputusan Kriteria Majemuk. Jakarta : PT.Gramedia Widiasarana Indonesia

Mitchell, B. 2015. Pengelolaan Sumber Daya Lingkungan. Yogyakarta: Universitas Gadjah Mada.
Nurdin Usman. 2014. Implementasi dalam Birokrasi Pembangunan. Bandung: Alumni.

Rahardyan B. dan Widagdo A.S. 2015. Peningkatan Pengelolaan

Persampahan Perkotaan Melalui Pengembangan Daur Ulang. Jakarta: Materi Lokakarya 2 Pengelolaan Persampaham di Propinsi DKI Jakarta.

Riswan, Henna Rya Sunoko dan Hadiyarto, Agus. 2011. "Pengelolaan Sampah Rumah Tangga di Kecamatan Daha Selatan". Jurnal Ilmu Lingkungan, Vol.9, No.1.April 2011. Program Studi Ilmu Lingkungan Program Pasca Sarjana Universitas Diponogoro.

Saxena, J.P. et.al. 1992. Hierarchy and Classification of Program Plan Element Using Interpretative Structural Modelling. Systems Practice, Vol 12 (6), 651:670.

Sudipa, N., Mahendra, M. S., Adnyana, W. S., Pujaastawa, I. B. 2020. Model Pengelolaan Lingkungan di Kawasan Pariwisata Nusa Penida, Bali; Journal Ecotrophic: 14 (1): 1-13

Sudipa, N., Mahendra, M. S., Adnyana, W. S., Pujaastawa, I. B. 2020. Tourism Impact on the Environment in Nusa Penida Tourism Area; Journal Inveronmental Management and Tourism: XI (41): 113-124 